\title{
Learning Activities Activating Kindergartners to Learn to Speak English in an EFL Indonesian Setting
}

\author{
Mindari, R. ${ }^{1}$ and Saukah, A. ${ }^{2}$ \\ ${ }^{1}$ Widya Mandala Catholic University, Surabaya, INDONESIA \\ e-mail: ruruhmindari@yahoo.com \\ ${ }^{2}$ The State University of Malang, Malang, INDONESIA \\ e-mail: alisaukah@yahoo.com
}

\begin{abstract}
The study tries to investigate what learning activities activating kindergartners to learn to speak English and to describe the language producion. It involves four kindergartners from different schools. The data were collected through observations and interviews and then analysed by constant comparisons. The findings revealed there were four commonalities of the learning activities, namely, (1) answering questions in English; (2) listening to a model speaking English; (3) imitating, and (4) repeating the English utterances. Among the four, answering questions was the most frequent way. Meanwhile, the language production varied covering single word utterances, verb phrases, simple sentences $(\mathrm{S}+\mathrm{V}+\mathrm{O})$ or $(\mathrm{S}+\mathrm{V}+\mathrm{O}+\mathrm{Adv}$.)in simple present tense, and exclamation. The proposition generated from the present study is that kindergartners will learn to speak English if they are often asked questions in English which they understand and are engaged in an interaction in English where they need to listen, imitate, and repeat.
\end{abstract}

Key words: Learning activities, kindergartners, learn, speak, interaction, scaffolding.

\section{INTRODUCTION}

As an impact of the global era, non-English speaking countries, including Asia, feel the role of English more and more significant today so that they start the English education much earlier in schools. As Paul (2003) puts it, millions of children in Asia are studying the language. Realizing the important roles of English and human resources who are competent in communication using the language in the information and globalization era, Indonesia has been actively practicing teaching English to young learners since the launching of the 1994 Curriculum. Elementary schools can start teaching English at the fourth grade (Decree of the Minister of National Education, 2006). Certain schools in big cities, however, even start it from the first grade. Further, preschools like kindergartens and playgroups also introduce English to the preschoolers.

As naturally happens, with all their characteristics, it is easier for children to attain another language compared to adults. It often happens to a family who moves to another country with a different language. The children will usually be able to communicate in the new language without too many difficulties. Accordingly, introducing a new language to young children while they are acquiring their first one will not cause problems to them as long as it is done properly.

Hammers and Blanc (2000) gave a more neutral argument by stating that younger children do not have any greater ability in learning a second language than older ones but they do have a less complex task with longer time. In line with the view, Pinter (2006) clarifies that the advantages of younger children's learning a new language are their intuitive grasp of language and their ability to be more attuned to the phonological system of the new language because they are more sensitive to its sounds, rhythm, and patterns of intonation. They enjoy copying them, and they have less anxiety and inhibition but, compared to older learners, young children have longer period to spend in learning the new language. In learning a foreign language in general, or specifically English in this context, older children or adults, on the contrary, might not want to sound English because they want to preserve their identity. The explanations about brain plasticity above are known as the Critical Period Hypothesis (CPH) proposed by Lenneberg (1967).

Young children naturally learn to understand everything they encounter in their daily life such as why they need to eat regularly or how to behave. For 
Indonesian young children living in Indonesia, learning English, however, is not something natural. Children aged four to six live in their own world - the world of play and imagination (Halliwell, 1992; Slattery \& Willis, 2001). They like to play in almost any situation and imagine an object or even a person as something else. In addition, they also get bored easily especially if involved in an activity that is not interesting for them. Having limited concentration span, they easily stop from an activity and switch to another, which attracts their attention more (Slattery $\&$ Willis, 2001). No wonder while the teacher is still telling a story, for example, a child may stand and walk around the room. Commonly, they cannot keep still for a long time in an activity because by nature a child is mobile.

As English is a foreign language in Indonesia, Indonesian children have very little or even no English exposure in their daily life. Except some from TV and from the teacher in the classroom, most of what they hear from the time they wake up in the morning up to the time they go to bed is Indonesian and/or a vernacular. Therefore, they are not accustomed to listening to English. Besides having minimum English exposure outside the classroom, kindergarten students, generally, are not yet able to read and write very well. In such a condition, they learn English, which is not easy.

As everyone experiences in everyday life, interaction makes people use language. Cook and Cook (2005) support that language development is the result of a complex interaction between the child's biological predispositions and social interactions. They argue that simply hearing language is not enough; therefore, interacting with other people is important. In other words, to develop language, children must have conversation with other people.

Since by nature humans are social being, children themselves play a significant role by seeking social interactions and trying to communicate with those around them such as parents, siblings, or other family members. At the school setting, other people here can be the teacher and/or peers. Therefore, the process of learning at school involves teacher and peers. The study investigated what learning activities that activate very young learners, specifically kindergartners, who are usually aged 4 to 6 , to learn to speak English. Meanwhile, it also aims at describing the young learners' English language production.

As the research focuses on the learning language in interaction, Vygotsky's (1978) learning theory of social constructivism is chosen as the theoretical framework of this study. This is based on the fact that children learn things including speaking while they are engaged in an activity and interaction with parents or a care giver, teacher, or other children.

When there is someone accompanying who is more knowledgeable than him or her, the child can go further in learning, more than he or she does without the support of others. This is what Vygotsky (1978) means by achieving the Zone of Proximal Development, a zone that is beyond the child's ability at the time. With his co-writers, Bruner (1976) introduced such help as 'scaffolding', a helpful involvement of someone more skillful to a learner to be able to complete something which is too difficult to do when $\mathrm{s} / \mathrm{he}$ is alone. The concepts above are used as the underlying principles of this study.

\section{METHOD}

This qualitative research is a multi-case study. The data were gathered by doing observations and interviews. The researcher went to some kindergartens to observe the subjects - kindergartners who can speak English for communication. Besides having the speaking ability, the subjects also met other criteria set as follows: (1) an Indonesian child of Indonesian mother and father, (2) born in Indonesia and had never lived in an English speaking country, (3) does not live in a circumstance where the people speak English, (4) can use English in oral communication despite the syntactical or phonological problems, and (5) there is only one person or nobody who speaks English in the child's home. These criteria were made for the sake of having the representatives of common Indonesian children and at the same time avoiding a condition that makes the subjects automatically acquire English.

There were four subjects in the study - two male and two female all aged 6-from three different kindergartens. Subject 1 (male aged 6) went to a government kindergarten located at Gresik, a town at East Java, Indonesia, which is known for its cement production and sea food. As the researcher saw it, all the female students and teachers wore the Moslemstyle dress. Subject 2 (male) and three (female), both aged 6 , were schoolmates. They went to a private kindergarten located at the Eastern part of Surabaya, the capital of East Java. Founded by a Christian couple who loved children, the atmosphere of the school was like a big Christian family. Subject 4 (female aged 6) went to a Catholic kindergarten of which the principal was a Catholic nun. The majority of the students of the kindergarten belong to the middle to higher class of families. 
Practically, the data sources of this study were the audiovisual records of the English instructions at school involving the subjects of the study and the English learning activities of the subjects at home. The data to be analyzed covered the young learners' participations in the learning activities, interaction and communication with the teacher as well as with peers in a small group during the English lessons or with parent/s at home in the process of learning English. Each collected data were then compared with the following ones by applying comparative analysis to generate a proposition.

The informants in this study were the subjects' parents and teachers of English. From interviews with the parents, the researcher obtained information about the children's interest and behaviors, socio-economy and cultural background, the subjects' activities of English learning, and the parents' involvements in the subjects' English learning; whereas from the teacher of English, information about the subjects' performance and achievement in the English lessons was gathered.

The data collection was not done at the same time for all subjects. There were four subjects from three different schools in the study. Subject 1 was from school A, Subjects 2 and 3, who were classmates, were from school B, and Subject 4 was from school C For Subject 1, who mainly learned English with his father at home, the researcher conducted home observations three times on every other week each lasted about 50 to 60 minutes. As Subject 1 had quit from the English Extra Curricular at school, the researcher only did one classroom observation lasted in 60 minutes to know the instructional activities that might have caused Subject 1 to quit. For Subjects 2 and 3, the classroom observations were conducted ten times, twice a week (Monday and Wednesday) each lasted 45 minutes. The home observation for the two subjects was once for each. For Subject 4, the classroom observations were done four times a week on Mondays, each 45 minutes, and one home observation. All data collection was done from January 17, 2011 to May 2, 2011.

The data were analyzed inductively by developing some propositions leading to theory generating. The flow of data analysis was as follows. It started from Open Coding, in which the subjects learning activities were coded by classifying them into themes or categories, i.e. answering Wh-questions, responding to a picture, or saying a routine. At this phase, looking for patterns among the categories was done to arrive at the core categories. After identification of core categories of the data, the analysis moved to Axial
Coding. In the axial coding, writing memos was done to figure out how categories were related. From the axial coding, it went on to the analysis of relationships between categories leading to statements of propositions.

The next stage was comparing the proposition with new data. The generation of theory was achieved through constant comparison of theoretical constructs with data collected from the new observations. The process of data collection and analysis were interrelated when the researcher collected, coded and analyzed the data at the same time. The proposition was constructed after each data collection and analysis, where the previous proposition was revised after the next data collection until the point of data saturation was reached. The last revised version of the proposition can be potentially developed into the theory generated in this study.

\section{FINDINGS AND DISCUSSION}

This section consists of two parts, the learning activities that activate kindergartners to learn to speak English and the language production of the young learners in the process of learning to speak English.

\section{The Activities Activating Kindergartners to Learn to Speak English}

The result of analyzing the data from all the four subjects shows that they learn to speak English in many different ways or learning activities. The various ways of learning to speak English can be ordered in terms of frequency of occurrence, from the most to the least frequency as shown in Table 1 .

The data presented in Table 1 above are the results of the observations of all subjects. Individually, the findings are represented in Table 2 below to find the commonalities.

From Table 2 above some commonalities were be found as follows: The kindergartners learned to speak English through (a) answering questions, (b) listening to the model's utterances, (c) imitating the model's utterances, and (d) repeating the model's utterances.

The most frequently used and commonly shared by the four subjects is answering wh-questions which means that kindergartners learn to speak English mostly by answering wh-questions. Translation frequently done by Subject 1 only, whereas other learning activities that were commonly shared by all subjects were listening, imitating, and repeating a model's speech. 
Table 1. Learning Activities Activating Kindergartners to Learn to Speak English

\begin{tabular}{lc}
\hline No. Category & f \\
\hline 1. Answering Wh. Questions & 103 \\
2. Translating & 58 \\
3. Answering Yes/No questions & 50 \\
4. Repeating word/s & 25 \\
5. Responding to a picture & 24 \\
6. Initiating communication & 13 \\
7. Through shared story reading & 12 \\
8. Imitating pronunciation & 11 \\
9. Reading sentences aloud & 10 \\
10. Answering an alternative question & 8 \\
11. Uttering a private speech & 8 \\
12. Doing a routine & 7 \\
13. Responding to greeting & 6 \\
14. Through singing songs and reciting chants & 5 \\
15. Agreeing or disagreeing & 4 \\
16. Completing a sentence & 3 \\
17. Writing sentences aided by pictures & 3 \\
18. Asking a question & 2 \\
19. Responding to a statement & 2 \\
20. Through one's interests (by watching and listening to an idol on TV or DVDs then imitating their speech). \\
21. Sharing the English knowledge & 2 \\
22. Answering by repeating the last word & 2 \\
23. Practicing guided question and answer & 1 \\
\hline
\end{tabular}

Table 2. Learning Activities Activating each Subject to Learn to Speak English

\begin{tabular}{llll}
\hline \multicolumn{1}{c}{ Subject 1 } & \multicolumn{1}{c}{ Subject 2 } & \multicolumn{1}{c}{ Subject 3 } & \multicolumn{1}{c}{ Subject 4 } \\
\hline $\begin{array}{l}\text { Answering questions; } \\
\begin{array}{l}\text { Listening to his father's } \\
\text { speech; }\end{array}\end{array}$ & $\begin{array}{l}\text { Answering questions; } \\
\text { Listening to the teacher's } \\
\text { speech; }\end{array}$ & $\begin{array}{l}\text { Answering questions; } \\
\text { Listening to the teacher's } \\
\text { speech; }\end{array}$ & $\begin{array}{l}\text { Answering questions; } \\
\text { Listening to the teacher's } \\
\text { speech; }\end{array}$ \\
$\begin{array}{l}\text { Imitating and repeating his } \\
\text { father's utterances; }\end{array}$ & $\begin{array}{l}\text { Imitating and repeating the } \\
\text { utterances of the teacher and } \\
\text { his idols on TV \& DVD; }\end{array}$ & $\begin{array}{l}\text { Imitating and repeating the } \\
\text { teacher's utterances; }\end{array}$ & $\begin{array}{l}\text { Imitating and repeating the } \\
\text { teacher's utterances; }\end{array}$ \\
$\begin{array}{lll}\text { Translating his father's } \\
\text { utterances into English; }\end{array}$ & $\begin{array}{ll}\text { Reading sentences aloud; } \\
\end{array}$ & $\begin{array}{l}\text { Singing songs and reciting } \\
\text { chants; }\end{array}$ \\
& & $\begin{array}{l}\text { Teaching/sharing her English } \\
\text { lesson to her mother and } \\
\text { maidservant. }\end{array}$ & $\begin{array}{l}\text { Practicing guided questions } \\
\text { and answers with a peer. }\end{array}$ \\
\hline
\end{tabular}

Since the early stage of data analysis of the study, the core category or the emerging theme of this study has been answering questions. After the findings from the four subjects are compared, answering questions is the most commonly shared among the subjects. It indicates that answering questions deserves a particular attention.

Answering a question is a natural and spontaneous reaction of anyone who is asked by somebody. In classroom activities, the teacher often asks students questions to check their understanding on the lesson as well as their involvement. Despite the difficulty with "why" questions, answering wh-questions in general appears to be the kind of communication with which kindergartners learn to speak English most frequently. This finding is surprising as the type of questions taught first at primary and junior high school is Yes/No questions.

Although answering Yes/No question also frequently appeared in the learning process, answering Whquestions occurred more frequently in this study. There is a possibility that the teachers or parents who teach English prefer to use Wh-questions to make young learners respond by mentioning one or two words in English rather than only saying 'Yes' or 'No.' When a child only has to answer a Yes/No question, she only needs to understand the question then says "Yes" or "No." The words used are limited. 
However, when the child has to answer a Whquestion, by mentioning one or two words, she does not only need to understand the question but also produces words from their memory or words storage. In this case, a Wh-question motivates three abilities: listening comprehension, knowledge of words, and pronunciation as well. In certain cases, it even triggers the production of syntactical response, the subject's answer "That is a water park!"

In a research about Wh. questions, Berent (1996) states that this type of questions plays the biggest role in English communication to ask for information about persons, things, events, time, place, reason, manner, etc. Further, the writer argues that the knowledge of Wh-questions is critical for learning. According to him, the ability to understand, to ask, and to answer questions in English is vital to educational success and later to success on the job. Besides Wh-questions, Yes/No questions also contribute to the process of English learning. This is because of its simplicity. Anyone needs only to say 'Yes' or 'No' if asked by using this type of questions. Therefore, it helps a lot in making kindergartners speak English.

Tracing back to the ancient Greek time, the so called 'elenchus' or the Socratic method, was a type of pedagogy used by Socrates where a series of questions were asked not only to draw individual answers but further to encourage fundamental insight into the issue at hand (McClellan, 1976). If the context is a foreign language classroom of very young learners, however, the goal is to invite individual answers. Even so, by answering questions, a child is practicing the language she is learning and at the same time expressing herself. If done frequently, she will get more used to speaking the language and it means she develops her skill in using the target language for communication.

Referring to Piaget's stages of development, kindergartners, whose age ranges from 4 to 6 , are on their preoperational stage. As the philosopher puts it, children on this stage thinks reliantly on perception but gradually, they become more and more capable of logical thinking (Pinter, 2006). The result of this study indicates that most frequent question they answer is a 'what' question, especially when they are learning new words. While asking a question to the children, "What is it?" the teacher is holding and showing a colored picture or flashcard. Then, from what they see, the children will answer the question, for example, "That is a flower."

Unlike answering 'what' question, answering a 'why' question is still hard for kindergartners. When a subject of this study was asked why she did not want to be a doctor, she could not give the reason but answered "I don't like" instead. Answering a 'why' question needs a reason which requires a reasoning ability. When speaking in a foreign language, the difficulty of the speaker is even greater because one has to think how to express the reason in the language. Even for adults, 'why' is the highest level of question, let alone for very young learners who cannot think and say about something abstract. The type of question belongs to 'analysis' level in Bloom's Taxonomy, or 'analyzing' in the revised version (Pohl, 2000). Someone needs to break down an idea or relate an effect to its cause to analyze something. Therefore, it is understandable if in general, it is hard for kindergartners to answer 'why' questions. That is why, perhaps, the teacher rarely or never asks this type of question.

Subject 1, however, was an exception in this case. Unlike the majority of kindergartners who are still in the first level-'knowledge' or 'remembering' level - he was already in the process of learning to answer 'why' questions, the fourth level from the bottom or the third from the top. When his father asked him why he felt so sad, he replied, "I feel so sad ... because ... I am hungry..." In other words, the child was learning logical thinking. His ability that went beyond that of other kindergartners on average was very much influenced by his father's effort to introduce him to English at home. His father's scaffolding him in his English learning has enabled him to reach a higher ability than that of kindergartners in general.

Answering questions in early language learning for very young learners always involves at least two persons: one person asking and another person answering the questions. It is a social interaction where communication likely happens. This is the one argued by Vygotsky (1978), who emphasized the importance of social interaction in the process of learning a language. The presence of another person who is more knowledgeable in English compared to the child will help the latter to reach a higher achievement up to its maximum rather than that when $\mathrm{s} / \mathrm{he}$ is learning alone (the concept of ZPD or Zone of Proximal Development).

Similar to Vygotsky's concept of ZPD, Bruner insisted on the importance of scaffolding in the process of language learning. To scaffold is like to give a hand temporarily until the child is able to perform certain ability. Scaffolding in a language classroom can be done by suggesting, praising the significant, providing focusing activities, and modeling (Cameron, 2001). 
Answering questions, translating sentences, repeating words, and responding to a picture involve the presence of an adult who is more competent in English with whom a child is learning. In other words, a child's success in learning to speak English mostly occurs in the interaction with an adult with better command of English. This is in line with Long's (1996) Interaction Hypothesis that states the development of language proficiency is promoted by face-toface interaction and communication.

Besides answering questions, translation seems to play a big role in a child's early process of learning English. Subject 1 learns English mostly by translating sentences. The subject first listens to his father's sentence in Indonesian, and then he translates it into English. This finding - learning to speak English by translating sentences - is similar to one of the findings of a research conducted by Mindari and Harjanto (2006) who investigated teacher's and young learners' language performance in holistic teaching English class. They found that during the instruction, the teacher sometimes asked her students to translate her Indonesian utterances into English. In a research of Language Learning Strategy Use of Chinese ESL Learners in Hong Kong, Wu (2008) also found translation as one of popular strategies used by his participants. However, Wu's participants were adults whereas the subjects in the present study are very young children. In the process of learning a language, imitating and repeating seem to play a big role. Despite Chomsky's theory of innate ability or Language Acquisition Device (LAD), studies have shown clearly that the very first attempts to produce speech are those to imitate single words (Tough, 1984). Viewed from the work of the brain, when a word is heard, the output from the primary auditory area is received by Wernicke's language area. Later, when the word is imitated or produced, the pattern is sent to the front from Wernicke's area to Broca's area, which controls the movements of the speech muscles (Lust \& Foley, 2004).

Aside from the theories about imitation-repetition mentioned, from our daily life we often encounter a toddler who always imitates anything he sees or hears because by nature children like to imitate. Halliwell (1992) even states that children have the instinct of talk and interaction. When learning a foreign language, imitation, which then is followed by repetition, might be the basic and most important one as the sound system is different from that in the native language.

The next issue is learning to speak English by responding to a picture. By nature, young children are easily attracted visually because their senses are actively involved in perceiving the world. They like to see pictures especially the colorful ones. As Suyanto, Gunadi, and Nisa' (2001) state that there are three sources of attention for children in the classroom: pictures, stories, and games. Out of the three, pictures are probably the ones that attract their attention instantly and stimulate them to give comments immediately, at least by identifying them.

As stated above, games are another effective source of attention. All children in this world naturally like to play because they have the instinct for play and fun (Halliwell, 1992). Children in the old days commonly played with simple games with peers but in this modern IT era, most children are familiar with electronic games using English instructions. By playing it, a child unintentionally learns English vocabulary such as start, finish, speed, jump, etc. or sometimes a command like 'Press number 2.' In such a situation, learning by doing happens. The child never has any intention to learn English but by playing it, he acquires some English words or sentences.

Considering answering questions as the predominant way for kindergartners to learn to speak English, it is important to see the kinds of questions that are effective for very young learners so that teachers as well as parents can communicate effectively with them and thus enhancing their speaking ability. As Hendrick (2003) emphasizes, teachers need to learn how to ask questions that invite children to respond. The questions should be a part of a conversation, not an interrogation. They should also relate to what the children are interested in and something that is familiar to them. According to the author, such questions invite the child's responses that the teacher really does not know yet and they put the child in the position of the authority. She also sets forth that if the teacher then gives non-judgmental replies to the child's answers, it will encourage the children to talk further.

Referring to the findings, the proposition generated in this study was kindergartners will learn to speak English if they are often asked questions in English which they understand and are engaged in an interaction in English where they need to listen, imitate, and repeat.

\section{The Language Production}

As there are four subjects in the study each with his or her own characteristics, the discussion of their language production below is presented per subject starting from Subject 1. 
Lexically, Subject 1 started producing English from nouns and verbs. The nouns he first learned and produced were the objects he saw surrounding him such as house, door, window, chair, table, lamp, TV, hand phone, books, toys, car, bicycle, mother (Mom) and father. In addition to the objects nearby, he also produced the words football and table tennis because the first sport is his hobby while the second is his father's. At this phase, he still spoke the words in isolation whenever his father asked him to say something in English.

The verbs he produced were also those telling about activities he did every day like do, go, eat, drink, play, sleep, wake up, buy, walk, run, sit, stand, read, ride, watch, and call. He knew other verbs which he got from electronic games such as start, finish, pause, stop, mute, or jump but he did not use them to speak yet.

As his father told the writer in an interview, after helping his son learning single words for about four months, he began to introduce phrases to Subject 1 . Therefore, the boy started to say and use verb phrases like 'play football', 'drink milk', 'watch TV', 'read book', or 'buy ice cream.' Generally, the phrases were about his daily activities so that it was not very difficult for Subject I to learn. Meanwhile, he also learned and started to say adverbs of time such as every day, every morning, A.M, and P.M.

Later on, with his father's guidance, Subject 1 could say simple sentences such as 'I watch TV', I play football', I go to school', and 'I want to buy ice cream.' His first sentences were mostly with subject 'I' because naturally, everyone, moreover a young child, is more interested in talking about himself. At this phase, his father also taught him to use prepositions like 'in', 'on', 'to', 'from', and 'with.' As a result, syntactically, Subject 1 could produce longer sentences, advancing from $\mathrm{S}+\mathrm{V}+\mathrm{O}$ pattern to $\mathrm{S}+\mathrm{V}+\mathrm{O}+$ Adverb. He could say sentences like 'I go to school every day', "I go to school with $B u$ De', 'I buy milk in Ruko', 'Father go to office by car', 'I play football with my friends', 'I can ride my bicycle', or 'Father play table tennis at Petro.'

So far, the sentences produced by Subject 1 were simple present ones minus the agreement markers (the ending-s/es) of the verbs for the third person singular pronoun. He had not produced a past-tense sentence either although sometimes he talked about something in the past because his father did not want to burden him with those structural elements too early. Once he tried to teach him to use a past tense form of a verb but it made Subject 1 confused and reluctant to speak.
As he was accustomed to translating utterances spoken by his father, his communicative ability was not balanced with his knowledge. However, after his father began to communicate with him in English in real situations, gradually Subject 1 can perform his speaking skill better. He is now getting used to answer his father's real questions in English.

Compared to that of Subject 1, the language production of Subject 2 in general is simpler but more communicative and natural. He sometimes uttered certain vocabulary for himself but he often answered the teacher's questions or even initiated a communication with her.

Lexically, his vocabulary was from the lessons in the classroom. Since the topics of the lessons during the observations were 'Pleasure Places' and "Names of Occupations,". Consequently, the words he produced were mostly of the two clusters. Hence, he often mentioned lexicons such as 'amusement park', 'water park', 'zoo', 'beach' and those like 'teacher', police officer', 'chef', or 'drummer.' The last word was special for him. He did not learn it from the teacher at school but from his DVDs of international drummers' performances as his hobby is playing drums.

Syntactically, the sentences he produced varied, sometimes $\mathrm{S}+\mathrm{V}+\mathrm{NP}$ (That is a water park!; I am a drummer.), $\mathrm{S}+\mathrm{V}$ (I know. I know.), or $\mathrm{S}+\mathrm{V}+\mathrm{O}$ (He wants a policeman). What he meant by "He wants a policeman" was "He wants to be a policeman."

Subject 2 was talkative and expressive. While doing tasks, he often uttered his new vocabulary, a phrase, or a sentence he liked. For examples, while coloring a picture, he said 'nurse', 'doctor', 'amusement park or 'This is it!' When responding to the teacher's examples of occupations, he once said 'I am a drummer!' and at another time 'I am a police officer.'

Compared with the other subjects, Subject 3 was perhaps the most outstanding one in terms of the linguistic level of her language production. She rarely talked but when she talked, it was always interesting. Once she spoke to her peers "The group close to me, sing together." This is a complex sentence originated from "The group that is close to me, let us sing together." Syntactically, the sentence is very advanced for a kindergartner who learns English as a foreign language. The omission of the personal pronoun and be (that is) after the subject showed the maturity of the language competence and performance as well.

In terms of structural elements, she already used suffix-s for verbs following the third person singular 
subject. It could be seen from her reading aloud at home. She read sentences like 'He wants to be a dentist' or 'She wants to be a doctor' fluently and correctly with ease. She also produced an exclamation spontaneously. When opening a certain page of the picture-story book that shows the wolf in the chimney almost falling down on the boiling water below it, Subject 3 spontaneously exclaimed "Oh my God!"

When answering questions after she read "The Three Little Pigs", Subject 3 used short answers like 'Three', 'Their mommy', or 'Little pigs' reflecting her comprehension of the story. It was the first time for her to read and hear the story but she could answer the number of the pigs, identify the mommy pig, the wolf, and mention the characteristic of the pigs. When she was asked whether she had English or Indonesian storybooks she answered in a complete sentence 'I have two' that referred to "I have both in English and in Indonesian."

The language produced by Subject 4 was not as advanced as that of Subject 3 but it was sufficiently communicative. The words she produced were the vocabulary which she had learned from the English lessons. During the observations, the teacher was reviewing "Transportations" and "Names of Occupations." Therefore, the vocabulary Subject 4 often mentioned were 'bicycle', 'car', 'bus', 'teacher', or 'pilot.'

She mostly spoke English when answering the teacher's questions. She used short answers or oneword utterance like 'Black' or 'Okay' but showed her understanding of the teacher's speech. However, she sometimes produced a full sentence with $\mathrm{S}+\mathrm{V}+\mathrm{O}$ pattern. For examples, when the teacher asked, "What fruit do you like?" she answered, "I like strawberry." Further, when the teacher asked what vegetable she liked she said, "I like carrot." She could also reply the researcher's greeting on the second day of observation by saying, "I am fine. Thank you."

Unlike other students of her class, she sometimes continued the teacher's instruction. Take for instance, when the teacher explained how to make a bookmark and said "After you finished, please color it, ..." Subject 4 continued it by saying "and cut it." In this case, she produced an imperative sentence $(\mathrm{V}+\mathrm{O})$ as she had heard from the teacher. When practicing a guided conversation with a partner, however, she produced Wh-questions ('What is it?' and 'What color is it?'). Meanwhile, her partner answered, 'It is a flower' and 'It is red.'

\section{CONCLUSION}

Kindergartners learn to speak English at school mostly by answering questions. Kindergartners also learn to speak English by listening to a model's speech - a teacher's or a parent's - then imitating and repeating it. In other words, kindergartners learn to speak English if they are often asked questions in English which they understand and are engaged in an interaction in English where they need to listen, imitate, and repeat.

Since interaction involving answering questions is the most effective way of kindergartners' learning to speak English, the proportion of question-answer activities in the classroom or at home should be carefully considered. In helping very young children learn to speak, the teacher or the parent/s should speak English with good pronunciation as they are the main or sometimes even the only source of English exposure to them.

\section{REFERENCES}

Arifin, I. (2009). The Bridging Programme. Yogyakarta: Aditya Media.

Berent, G. P. (1996). Learnability constraints on deaf learners' acquisition of English wh-questions. Journal of Speech and Hearing Research, 39, 625- 642.

Cameron, L. (2001). Teaching languages to young learners. Cambridge: Cambridge University Press.

Cook, J. L. and Cook G. (2005). Child development: Principles and perspectives. Boston: Pearson Education, Inc.

Halliwell, S. (1992). Teaching English in the primary classroom. New York: Longman Publishing.

Hammers, J. F. \& Blanc, H. A. (Eds.). (2000). Bilinguality and bilingualism ( $2^{\text {nd }}$ ed). New York: Cambridge University Press.

Hendrick, J. (2003). Total learning: Developmental curriculum for the young child ( $6^{\text {th }}$ ed.). New Jersey: Merrill Prentice Hall.

Lenneberg, E. (1967). Biological foundations of language. New York: John Wiley.

Long, M. (1996). The role of the linguistic environment in second language acquisition. In W.R. Ritchie, \& T. J. Bhatia, (eds). Handbook of second language acquisition. San Diego: Academic Press. pp. 413-468.

Lust, B. C., \& Foley, C. (Eds.). (2004). First language acquisition: The essential readings. Victoria: Blackwell Publishing Ltd.

McClellan, J. E. (1976). Philosophy of education. New Jersey: Prentice Hall, Inc. 
Mindari, R., \& Harjanto, I. (2006). Teacher's and young learners' language performance in holistic English language teaching class. A research report presented in the 54th TEFLIN International Conference in Satya Wacana Christian University, Salatiga, 4-6 December 2006.

Ministry of National Education. (2006). Decree of the minister of national education no. 22/2006 on content standard, the national standards of education, Appendix \#1. Jakarta: Ministry of National Education.

Paul, D. (2003). Teaching English to children in Asia. Hong Kong: Longman Asia ELT.

Pinter, A. (2006). Teaching young language learners. Toronto: Oxford University Press.

Pohl, M. (2000). Learning to think, thinking to learn: Models and strategies to develop a classroom culture of thinking. Cheltenham, Victoria: Hawker Brown low.
Slattery, M., \& Willis, J. (2001). English for primary teachers. Oxford: Oxford University Press.

Suyanto, K. E., Gunadi, H.S., Nisa', J. (2001). Pengembangan paket model pembelajaran bahasa Inggris sebagai mata pelajaran muatan lokal di sekolah dasar. [Academic Report RUT VIII.I, 2001]. Malang: Universitas Negeri Malang.

Tough, J. (1984). Young children learning languages. In C. Brumfit, J. Moon, \& R. Tongue (Eds.), Teaching English to children from practice to principle, pp. 213-227. London: Nelson.

Vygotsky, L. S. (1978). Mind and society: The development of higher mental processes. Cambridge, MA: Harvard University Press.

Wood, D. J., Bruner, J. S., \& Ross, G. (1976). The role of tutoring in problem solving. Journal of Child Psychiatry and Psychology, 17(2), 89-100.

$\mathrm{Wu}, \mathrm{M} . \mathrm{M}$. (2008). Language learning strategy use of Chinese ESL learners in Hong Kong. Electronic Journal of FLT, 5(1), pp. 68-83. 